\title{
Are euro-area corporate bond markets irrelevant? The effect of bond market access on investment
}

von Beschwitz, Bastian and Conor T. Howells

Please cite paper as:
von Beschwitz, Bastian and Conor T. Howells (2016). Are
euro-area corporate bond markets irrelevant? The effect of
bond market access on investment. International Finance
Discussion Papers 1176.
http://dx.doi.org/10.17016/IFDP.2016.1176

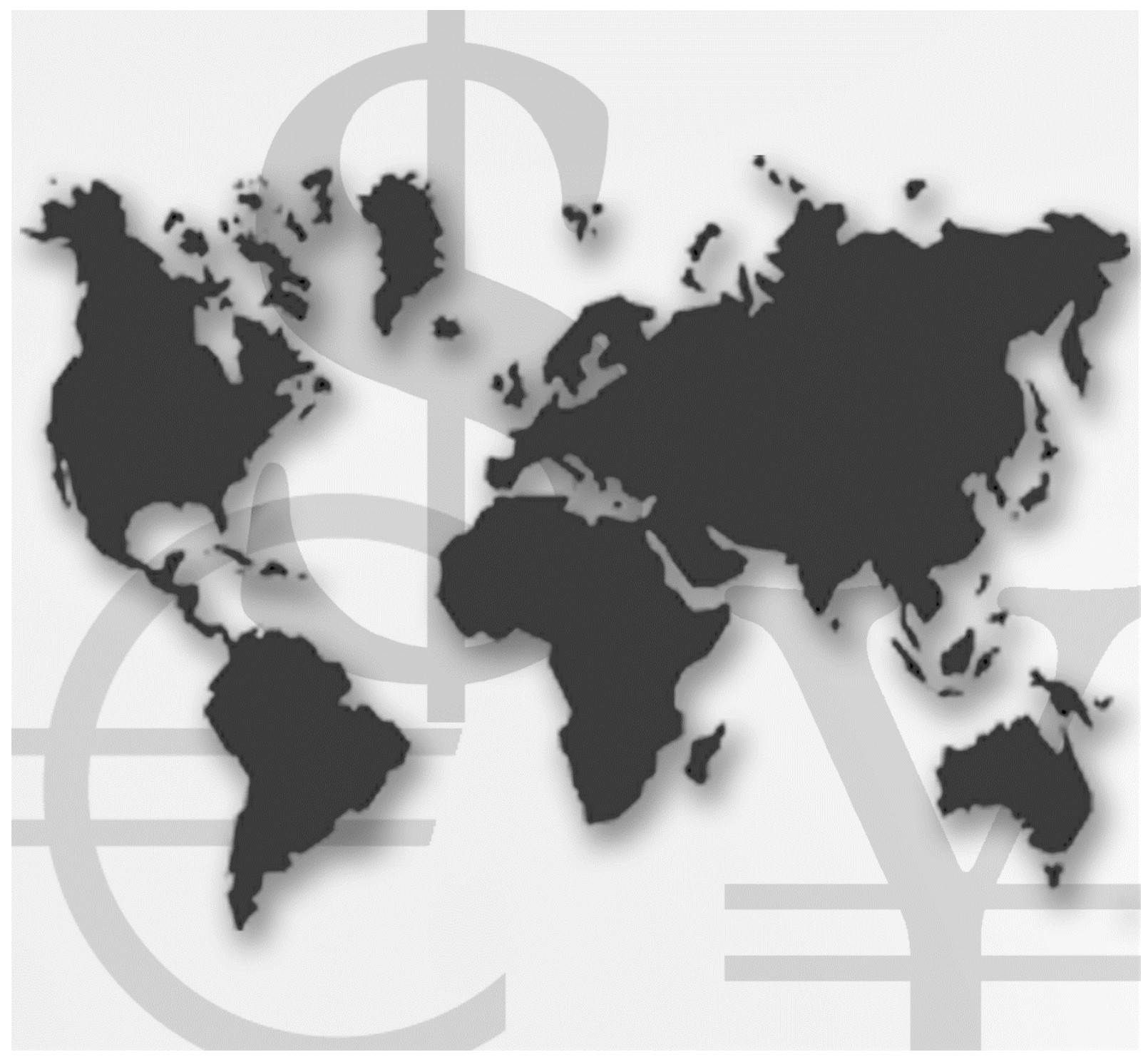

\section{International Finance Discussion Papers}

Board of Governors of the Federal Reserve System

Number 1176

August 2016 
Board of Governors of the Federal Reserve System

International Finance Discussion Paper

Number 1176

August 2016

Are euro-area corporate bond markets irrelevant?

The effect of bond market access on investment

Bastian von Beschwitz

Conor T. Howells

NOTE: International Finance Discussion Papers are preliminary materials circulated to stimulate discussion and critical comment. References to Internatoinal Finance Discussion Papers (other than an acknowledgment that the writer has had access to unpublished material) should be cleared with the author or authors. Recent IFDPs are available on the Web at www.federalreserve.gov/pubs/ifdp/. This paper can be downloaded without charge from Social Science Research Network electronic library at www.ssrn.com. 


\title{
Are euro-area corporate bond markets irrelevant?
}

\section{The effect of bond market access on investment*}

\author{
Bastian von Beschwitz ${ }^{\dagger}$ and Conor T. Howells ${ }^{\ddagger}$
}

June 30, 2016

\begin{abstract}
We compare how bond market access affects firms' investment decisions in the United States and the euro area. Having a bond rating enables US corporations to invest more and undertake more acquisitions. In contrast, in the euro area, bond ratings have no effect on investment decisions. Similarly, firms with bond ratings have higher leverage in the United States, but not in the euro area. This difference may be due to euro-area firms getting sufficient financing from banks. Consistent with this explanation, euro-area bond ratings became more relevant for investment after the banking crisis of 2008 , when banks reduced their lending to firms.
\end{abstract}

JEL classification: G31, G32, G34

Keywords: Mergers and acquisitions, Bond ratings, Investment, Financing constraints

\footnotetext{
${ }^{*}$ The views in this paper are solely the responsibility of the authors and should not be interpreted as reflecting the views of the Board of Governors of the Federal Reserve System or any other person associated with the Federal Reserve System. Special thanks to Federal Reserve seminar participants for helpful comments.

${ }^{\dagger}$ Bastian von Beschwitz, Federal Reserve Board, International Finance Division, 20th Street and Constitution Avenue N.W., Washington, D.C. 20551, tel. +1 202475 6330, e-mail: bastian.vonbeschwitz@frb.gov (corresponding author).

${ }^{\ddagger}$ Conor T. Howells, Federal Reserve Board, International Finance Division, 20th Street and Constitution Avenue N.W., Washington, D.C. 20551, tel. +1 202475 6379, e-mail: conor.t.howells@frb.gov.
} 


\section{Introduction}

Under the assumption of perfect capital markets (e.g. Modigliani and Miller (1958)), a firm's investment policy is independent of its financing. However, in reality, capital markets are not perfect and firms must forego profitable projects due to financial constraints. When profitable projects are not undertaken, welfare is lost, which is one of the reasons why developed capital markets are good for economic growth (e.g. Rajan and Zingales (1998), King and Levine (1993)).

While the academic literature generally focuses more on equity markets, U.S. firms actually raise more funds via bond issuance than via equity issuance. For example, in 2015, U.S. non-financial firms had a net issuance of bonds worth $\$ 400$ billion, which was more than double their issuance of equity ( $\$ 174$ billion). ${ }^{1}$ Compared to the United States, corporate bond markets have a much lower importance in the euro area: While total issuance of corporate bonds was 1.7 percent of GDP in the United States in 2005, it was only 0.9 percent in the euro area and, similarly, small and medium enterprises (SMEs) in the United States receive five times as much financing from capital markets as SMEs in Europe. ${ }^{2}$

Hoping to promote economic growth, recent policy initiatives in Europe have been designed to increase the importance of the corporate bond market. For example, the European Commission proclaimed the goal to create a Capital Market Union, which it defines as "a true single market for capital" within the 28 member states of European Union. ${ }^{3}$ Similarly, in March 2016, the European Central Bank (ECB) decided to purchase corporate bonds as part of its quantitative easing program. By increasing the demand for corporate bonds, the purchase program of the ECB may increase the size and liquidity of the corporate bond market in the euro area.

Would a larger bond market in the euro area really allow firms to invest more? How much would firm investment increase if the euro-area corporate bond market had the same size as its counterpart in the United States? We address these questions by comparing how bond market access affects

\footnotetext{
${ }^{1}$ These values are based on aggregating data from Securities Data Company.

${ }^{2}$ According to the "Action Plan on Building a Capital Markets Union" (http://ec.europa.eu/finance/capital-marketsunion/docs/building-cmu-action-plan_en.pdf)

${ }^{3}$ See for example the "Action Plan on Building a Capital Markets Union" (http://ec.europa.eu/finance/capital-marketsunion/docs/building-cmu-action-plan_en.pdf)
} 
firm investment in the euro area and the United States. Following Harford and Uysal (2014) and Faulkender and Petersen (2006), we use the fact that firms without a bond rating generally cannot access bond markets. Therefore, we compare how investment and leverage differs between firms with and without a bond rating in the United States and the euro area. Our main finding is that having a bond rating affects investment and capital structure in the United States, but not in the euro area.

To enable a direct comparison between Europe and the United States, we use only datasets with detailed global coverage: We obtain information on S\&P and Moody's issuer credit ratings from Moody's CreditEdge. We match this information to balance sheet data provided by Worldscope and acquisition information from Thomson Reuter's SDC Platinum. Our sample period runs from 2005 to 2014.

We start by focusing on the United States. We find that bond ratings affect firm investment policies in the United States. Controlling for various other characteristics, a U.S. corporation is 3.5 percentage points more likely to undertake an acquisition in a given year if it has a bond rating. This is an increase of 23 percent compared to the average acquisition probability of 14.9 percentage points. Firms with a bond rating also spend more on acquisitions (as a share of their assets). Furthermore, capital expenditures, as a share of assets, are 0.8 percentage points higher for firms with a bond rating. This is an increase of 24 percent compared to the median capital expenditure to assets share of 3.3 percentage points. In sum, these findings suggest that U.S. firms without a bond rating are financially constrained, which leads them to invest less than firms with a bond rating. Our results confirm prior evidence by Harford and Uysal (2014) who find that U.S. firms with a bond rating undertake more acquisitions.

However, when we conduct the same analysis on our sample of euro-area firms, we find no effect of bond ratings on investment: European firms with a rating are only an insignificant 0.7 percentage points more likely to undertake an acquisition. Furthermore, the effect of having a rating on the value of acquisitions and capital expenditures is actually insignificantly negative. Next, studying a combined dataset of euro-area and U.S. firms, we show that the difference in the effect of bond ratings on capital expenditures and the value of acquisitions between the United States and the 
euro area is also statistically significant. Taken together, these findings suggest that access to bond markets in the euro area is irrelevant to a firm's investment decisions.

How do we explain these surprising differences between the United States and the euro area? We propose two potential explanations: the weak bond market hypothesis and the strong banking hypothesis. The weak bond market hypothesis suggests that bond market access is less important in the euro area because bond markets in the euro area are underdeveloped and cannot supply sufficient amounts of financing. Thus, even euro-area firms with bond market access are financially constrained and would like to access a stronger bond market. This hypothesis assumes one or both of the following: either there are not sufficient funds available through the bond market, or the funds are too expensive to be attractive. In contrast, the strong banking hypothesis argues that good access to bank financing in the more bank-based euro area makes bond market access redundant. This hypothesis assumes that all euro-area firms have good access to financing through their banks and thus do not need access to bond markets.

If the weak bond market hypothesis were true, we would expect euro-area firms with a bond rating to expand investment to the levels of their U.S. peers if the euro-area bond market was able to grow to the size of the its U.S. counterpart. We estimate this increase in investment to be $\$ 100$ billion or approximately 0.8 percent of euro-area GDP. However, we would not expect these benefits to materialize under the strong banking hypothesis.

We try to distinguish between these two hypotheses by focusing on a time when bank lending was severely constrained: the financial crisis of 2008. The financial crisis was mainly a banking crisis and corporate lending by banks contracted significantly following the crisis (Becker and Ivashina (2014)). If the strong banking hypothesis is correct, and our results are at least partly explained by the importance of bank financing in the euro area, we would expect bond ratings to become more important at such a time because bank loans are unavailable. Indeed, we find that this is the case. We estimate a difference-in-difference set-up examining the change in the effect of bond rating on capital expenditures following the financial crisis. We find that having a bond rating becomes more important in the euro area after the financial crisis. The relative increase in capital expenditures as a fraction of assets for firms with a bond rating is 0.6 percentage points, or 17 percent relative to 
the mean, consistent with the strong banking hypothesis. Taken together, our results suggest that in normal times bond market access is not important to investment in the euro area, as firms have access to enough bank financing. However, after the crisis, when bank financing became scarce, euro-area firms with a bond rating could invest more relative to their unrated peers.

In addition to investments, we find that having a bond rating also has a differential effect on capital structure in the euro area and the United States. While we confirm the results of Faulkender and Petersen (2006) that firms with a bond rating have higher leverage in the United States, we do not find any effect of bond ratings on leverage in the euro area. The difference in the effect of bond ratings on leverage (defined as debt over market value of equity) between the euro area and the United States is about 10 percentage points, which is economically large and statistically significant at the 1 percent level. This additional result shows a potential negative effect of stronger bond markets: If stronger bond markets allow firms to take more leverage, they may be more likely to go bankrupt in an economic downturn.

In our analyses, we follow the assumption of Harford and Uysal (2014) and Faulkender and Petersen (2006) that the lack of a bond rating is a supply-side effect rather than indicating the missing demand for a rating, i.e. we assume that there is no reverse causality. To support this assumption, we show in a robustness check that our results hold when lagging our rating dummy variable by two years. Furthermore, we control for many firm characteristics that could be correlated with having a rating. More generally, given that we mainly focus on the difference between the United States and the euro area, our results are somewhat less subject to endogeneity concerns. Indeed, for our results to hold, bond market access must not be totally exogenous: It is enough if the endogeneity bias is similar in the euro area and the United States, a much milder assumption.

Our paper has important policy implications for the debate on capital market development in the European Union. Our findings suggest that euro-area bond markets are irrelevant for investment, implying that there may be potential to boost investment by creating stronger capital markets. However, this conclusion is limited by our evidence in favor of the strong banking hypothesis, which implies that bond market access may have been irrelevant before the crisis, because firms had access to sufficient bank financing. If bank financing is sufficient, one would not expect improved bond 
market financing to lead to an increase in investment.

Our paper contributes to a broad literature on the effect of financing on investment choices. Many papers in that literature study the effect of internal financing via investment-cash flow sensitivities and debate how to interpret the results of investment-cash flow regressions. ${ }^{4}$ Other papers study how access to external financing affects investment. Measures of access to external financing include the amount of collateral available (Gan (2007), Chaney, Sraer and Thesmar (2012)), negative shocks to the health of the firm's banks (e.g. Peek and Rosengren (2000), Schnabl (2012)), and the amount of debt maturing (Almeida et al. (2009)). Our paper is most closely related to studies that use the existence of a bond rating as a proxy for access to external financing. For example, Chava and Purnanandam (2011) show that U.S. firms with a debt rating are less negatively affected by the Russian crisis in 1998, which is used as a negative shock to bank lending. Sufi (2009) shows that firms with a syndicated bank loan rating undertake more cash acquisitions. Faulkender and Petersen (2006) show that firms with a corporate bond rating have higher leverage, and Harford and Uysal (2014) show that firms with a corporate bond rating undertake more acquisitions. We make the important contribution that the positive effect of a bond rating on investment depends on the institutional environment of the firm by showing that no such effect can be found in the euro area.

Furthermore, our paper adds to a literature that studies the effect of capital market development on economic growth. This literature finds mixed results. While Rajan and Zingales (1998) and King and Levine (1993) find that developed financial markets are beneficial for growth, Cecchetti and Kharroubi (2012) and Law and Singh (2014) show that financial development is only beneficial to growth up to a certain threshold. Our paper provides insight into these contrasting results by showing that certain conditions need to be met for market access to have a positive effect on investment. We show that in a bank-based economy, such as the euro area, having access to a bond market is much less important but can gain importance when the banking system experiences a

\footnotetext{
${ }^{4}$ These papers study investment-cash flow sensitivities: Fazzari, Hubbard and Petersen (1988), Hoshi, Kashyap and Scharfstein (1990), Whited (1992), Almeida and Campello (2007), while these paper debate how investment-cash flow sensitivities should be interpreted: Fazzari, Hubbard and Petersen (2000), Kaplan and Zingales (1997), Kaplan and Zingales (2000), Erickson and Whited (2000), Gomes (2001), Alti (2003), Moyen (2004).
} 
negative shock.

The rest of the paper is structured as follows. In Section 2, we describe our data. In Section 3, we present our empirical results. In Section 4, we present robustness checks and Section 5 concludes the paper.

\section{Data}

In this section, we describe the construction of the dataset and present summary statistics.

\subsection{Sample and Variable Construction}

We create a yearly panel of firms in the United States and the euro area by merging the following three datasets: issuer rating information from Moody's Analytics, firm balance sheet information from Worldscope, and acquisition information from Thomson's SDC platinum. All three data sources provide coverage for both the United States and the euro area, which ensures comparability. We restrict our sample to years from 2005 to 2014, because Moody's Analytics is only available from 2004, and we lag independent variables by one year.

We will now describe our three data sources in more detail. Moody's Analytics provides data on whether a firm has either an S\&P or a Moody's firm-level issuer rating at a daily frequency. We aggregate this information at the yearly level. We define Rating as a dummy variable equal to one if the firm has an S\&P and/or a Moody's issuer rating at the end of the year.

Using firm ISIN, we merge this information with consolidated balance sheet information from Worldscope. Worldscope is the standard data source for international balance sheet information of publicly-listed companies and has been used in many studies (e.g. Faccio and Masulis (2005)). We use Worldscope to obtain information on capital expenditures, cash and EBITDA - all as a fraction of total firm assets - as well as market-to-book and leverage ratios. We follow Harford and Uysal (2014) in constructing these variables. We present more details on variable construction in Appendix B. 
We use acquisitions data from Thomson's SDC platinum. Following Harford and Uysal (2014), we only include acquisitions that fulfill the following two criteria: the acquisitions must be "domestic" -defined as U.S. acquisitions for U.S. firms and euro-area acquisitions for euro area firms- and the ratio of the total value of an acquirer's acquisitions in a year to the acquirer's total assets in the year prior must be greater than one percent. After these filters, we are left with 3,374 acquisitions for the United States and 863 acquisitions for the euro area. Using these acquisitions, we construct the following two yearly variables: Acquisition Dummy, which is equal to one if the firm undertakes at least one acquisition in a given year and Acquisition Value, defined as the aggregate value of all qualifying acquisitions in a year divided by the acquirer's total assets. For firms in the United States, we match this information to our dataset using the CUSIP of the acquirer or its ultimate parent, while we use the SEDOL of the acquirer or its ultimate parent for euro area firms.

On our combined dataset, we employ the following filters that follow Harford and Uysal (2014): we exclude financial firms and regulated utilities (SIC codes 6000-6999 and 4900-4999), drop firms with sales under 10 million when adjusted to 1990 U.S. dollars, and keep only observations where no independent and dependent variables are missing. Our final dataset includes 22,573 firm-year observations for the United States and 15,054 for the euro area. To limit the effect of outliers, we further winsorize all continuous variables at the 1 and 99 percent level. All euro area information is converted to U.S. dollars using year-end exchange rates.

\subsection{Summary Statistics}

In Table 1, we display summary statistics for the United States and the euro area. As one would expect given the smaller bond market, only 7.8 percent of euro area firms are rated compared to 34.2 percent in the United States. In Appendix A, we present country-level summary statistics for Rating, CAPX and the number of acquisitions. Euro-area countries differ in how many firms have a rating. While Luxembourg with 31.4 percent of firms being rated is close to the United States, in Greece - the country with the fewest ratings - only 2 percent of firms have a rating. The largest economies are close to the sample mean, with 8.3 percent of German and 9.7 percent of French firms having a rating. 
Similarly, acquisitions are less common in the euro area: the probability of undertaking an acquisition is only 5.7 percent compared to 14.9 percent in the United States. Furthermore, the value of acquisitions as a share of assets is only 0.6 percent compared to 2.7 percent in the United States. Euro area firms also spend less on capital expenditures: the median firm has capital expenditures of 2.4 percent of assets in the euro area compared to 3.3 percent in the United States. While firms in the two samples are of roughly similar size in terms of assets, U.S. firms have higher sales (mean of 2.7 billion vs. 1.7 billion).

Firms in the United States seem to be in better financial conditions: their average leverage (defined as debt over market value of equity) is only 35 percent compared to 50 percent in the euro area and they on average hold almost twice as much cash as a fraction of assets. More generally, U.S. firms seem to be more profitable. They have higher average earnings of 9.7 percent compared to 7.4 percent for euro-area firms, higher average stock returns (15.1 percent vs. 9.9 percent), and a higher market-to-book ratio of (1.88 vs 1.03). While there are clear differences between firms in the United States and the euro area, it is unlikely that they are driving our results. In fact, given that euro-area firms have weaker financial conditions, we would expect their investment to be more responsive to their access to external financing, which would make bond market access more important for euro-area firms. It must be noted that some of the differences may be due to different accounting standards in the two regions.

The summary statistics for our United States subsample are fairly similar to those in Harford and Uysal (2014), which are based on COMPUSTAT/CRSP data. This gives us confidence in using Worldscope data for the United States.

\section{Results}

\subsection{Bond market access and investment in the United States}

In this subsection we study how access to bond markets affects investment in the United States. This question is addressed by Harford and Uysal (2014), who find that firms with a rating are more likely 
to undertake an acquisition. To replicate their analysis, we regress Acquisition Dummy on Rating in our panel of U.S. firms. We follow Harford and Uysal (2014) and control for several variables that likely affect the acquisition probability and may be correlated with having a rating. These variables include the following: firm size, measured by the logarithm of sales, cash holdings, leverage, prior year's stock return, market-to-book ratio and earnings. We also control for two industry specific variables: market concentration within the industry measured as the Herfindahl index and M\&A liquidity measured as the value of acquisitions in the industry divided by the industry's total assets. We form industries based on 3-digit SIC codes. We also include year fixed effects. Because our dependent variable, Acquisition Dummy, is binary, we run a probit regression. To account for autocorrelation within firms, we cluster standard errors at the firm level.

The results are presented as Regression 1 in Table 2. We clearly confirm the finding of Harford and Uysal (2014) that U.S. firms with a rating undertake more acquisitions. According to our results, a U.S. corporation is 3.5 percentage points more likely to undertake an acquisition in a given year if it has a bond rating. This is slightly smaller than the 4.6 percentage points increase that Harford and Uysal (2014) find, but still constitutes an increase of 23 percent relative to the mean acquisition probability. Also, our control variables generally affect acquisitions in the same direction as in Harford and Uysal (2014) with the exception of Cash, which is insignificant.

Next, we extend their paper by studying how much firms spend on acquisitions. We use Acquisition Value as the dependent variable, which is defined as the total value of all acquisitions made within a year as a share of the firm's assets. Because this variable is continuous, we use OLS rather than probit analysis though otherwise the set-up is the same as before. We present the result in Regression 2 of Table 2. We find that U.S. firms with a rating spend 0.6 percent of assets more on acquisitions than firms without a rating, which corresponds to a 22 percent increase relative to the sample mean. This finding shows that rated U.S. firms spend more on acquisitions in addition to being more likely to undertake them.

Besides acquisitions, firms can also invest via capital expenditures. Thus, we now study whether U.S. firms with a rating also have higher capital expenditures. We use the same regression set-up as before, but drop $M \mathscr{E} A$ liquidity and the Herfindahl index, because these control variables are 
specific to analyzing acquisitions. We present the result in Regression 3 of Table 2 . We find that U.S. firms with a rating spend 0.8 percent more of assets on capital expenditures per year. This value corresponds to a 15 percent increase relative to the sample mean. Thus, debt market access leads not only to more acquisitions, but also to higher capital expenditures. Taken together, our results confirm the findings of Harford and Uysal (2014) for the United States subsample: bond market access seems to reduce a firm's financial constraints and allows it to invest more, both through higher capital expenditures and more acquisitions.

\subsection{Bond market access and investment in the euro area}

We proceed by testing whether bond market access also increases investment in the euro area. We conduct the same analysis used in our United States subsample for our subsample of euro area firms. We present the results in Regressions 4 to 6 of Table 2. In contrast to our results for the United States, we are unable to detect any effect of bond ratings on investment in our euro-area sample. The marginal effect of having a rating on the annual acquisition probability of firms in the euro area is only 0.7 percentage points and this effect is not statistically significant. Moreover, the effect of having a rating on the value of acquisitions and capital expenditures as a percentage of assets is actually insignificantly negative. In sum, these results suggest that having access to the bond market has no effect on investment in the euro area.

Furthermore, we test whether the difference in the effect of having a rating between the United States and the euro area is statistically significant. For this analysis, we study a combined sample including both euro-area and U.S. firms. Our explanatory variable of interest is an interaction between Rating and Euro Area, which is a dummy variable equal to one for firms in the euro area. We use the same dependent and control variables as before. In addition, we include each control variable interacted with Euro Area to allow control variables to have a different effect in the United

States and the euro area. Different effects of control variables may be driven by differences in the institutional environments, accounting rules and taxation rules.

We present the results in Table 3 . The effect of having a rating on the probability of undertaking 
an acquisition is 1.7 percentage points lower in the euro area. While this difference is large, it is not statistically significant. The effect of having a rating on the value of acquisitions is 0.7 percentage points lower in the euro area, which is significant at the 1 percent threshold. Similarly, having a rating increases capital expenditures by 0.9 percentage points less in the euro area, which is also significant at the 1 percent threshold. In sum, our results suggest that bond market access has almost no effect on investment in the euro area and that the effect of bond market access is substantially less important in the euro area than in the United States.

\subsection{Why is corporate bond market access less important in the euro area?}

In this section, we discuss potential explanations for the surprising result that corporate bond market access has almost no effect on investment in the euro area, while it has a large effect in the United States. In particular, we will relate this finding to the theory of financial constraints. According to this theory, firms are financially constrained from undertaking profitable investment opportunities. If these constraints are lifted, firms can invest more. With respect to this theory, our findings suggest that bond market access alleviates financial constraints in the United States, while it does not change financial constraints for euro-area firms. There are two fundamental explanations why bond market access does not affect financial constraints in the euro area. We will refer to them as the weak bond market hypothesis and the strong banking hypothesis.

The weak bond market hypothesis states that bond market access is less important in the euro area, because bond markets in the euro area are underdeveloped and can supply only little financing. Indeed, the EU investment grade corporate bond market is only about 60 percent the size of the US corporate bond market and the high yield market is only a third the size of the US market. ${ }^{5}$ Thus, there may not be sufficient funds available through the corporate bond market and/or the available funds may be too expensive to be attractive. According to the weak bond market hypothesis, even euro-area firms with bond market access are financially constrained and would like to access a stronger bond market.

\footnotetext{
${ }^{5}$ See "Stimulating EU corporate bond and equity markets" http://www.eurofi.net/wpcontent/uploads/2014/09/Stimulating-EU-corporate-bond-Web.pdf
} 
In contrast, the strong banking hypothesis argues that good access to bank financing in the more bank-based economies of the euro area makes bond market access redundant. Bank financing plays a much more prominent role in the euro area: In 2001, bank loans to the corporate sector were 43 percent of GDP in the euro area, while they were only 19 percent of GDP in the United States (De Fiore and Uhlig (2005)). The literature has proposed several reasons why bank financing can be cheaper than bond financing: For example, banks may have an advantage in monitoring the borrower (Diamond (1984)), they may have access to inside information (Fama (1985)) and they may have better incentives to monitor and acquire information (Boot and Thakor (2010)). Thus, the finding that bond market access matters less in the euro area may not be driven by the weakness of the euro-area bond market, but the strength of the euro-area banking system. Indeed, if all euro-area firms have sufficient access to financing through their banks, we would expect the bond market to have little effect on investment decisions. Under this assumption, all euro-area firms are financially unconstrained, even those that do not have a bond rating.

In the remainder of the paper, we examine which of the two hypotheses is more likely to drive our results. This question has profound policy implications. If the weak bond market hypothesis is true, euro-area investment and growth could be improved by regulation that supports a stronger bond market in the euro area. We can use our results to estimate how much investment in the euro area may go up if its bond market were as strong as the one in the United States (and the weak bond market hypothesis holds). As mentioned above, the differential effect of having a bond rating in the United States vs. the euro area is 0.7 percent on acquisitions and 0.9 percent on capital expenditures. If euro-area firms with a bond rating increase their investment activity by that much, it would result in yearly additional investments of approximately $\$ 100$ billion ( $\$ 45$ billion via acquisitions and $\$ 57$ billion via capital expenditures), because euro-area firms with a rating have combined assets of $\$ 6.4$ trillion. However, the effect might be even larger if bond ratings would become as prevalent in the euro-area as in the United States. In the United States, rated firms account for 92 percent of total assets of publicly-traded companies, while it is only 68 percent in the euro area. If 92 percent of euro-area firms were rated (by assets), the effect of a stronger bond market on investment could be $\$ 138$ billion ( $\$ 60$ billion via acquisitions and $\$ 78$ billion via 
capital expenditures) per year, which corresponds to 1.1 percent of GDP. ${ }^{6}$

However, these calculation only hold under the weak bond market hypothesis. In contrast, if the strong banking hypothesis is true, it implies that the irrelevance of the euro-area bond market is no reason for concern. Rather, one might argue that U.S. regulators should try to improve the U.S. banking system to relieve financial constraints to U.S. firms without a bond rating. Of course, both hypotheses are highly stylized and they may both be true to some extent. Also possible are interactions between the two hypotheses. For example, a strong banking system may prevent the development of a strong corporate bond market or vice versa.

\subsection{Change in bond market importance after the financial crisis}

In this section, we try to distinguish between our two hypotheses by studying how the importance of the bond market changed after the financial crisis of 2008. We use the fact that the financial crisis was mainly a banking crisis, and that corporate lending by banks contracted significantly following the crisis (Becker and Ivashina (2014)). If the strong banking hypothesis is correct, and our results are explained by the importance of bank financing in the euro area, we would expect bond ratings to become more important at such a time as bank financing becomes unavailable.

We run a difference-in-difference regression to examine how investment changes for firms with and without a rating after the crisis.We use 2009 to 2014 as the post-event period and 2005 to 2007 as the pre-event period. We exclude the year of 2008, because bank funding to firms only started to contract strongly towards the end of 2008. Our treated group consists of firms that have a rating in 2004, the first year of our sample. We fix Rating at the beginning of the sample period to avoid endogeneity issues, and to ensure that our treatment group does not change from one year to the next. Because it is unlikely that firms undertake many acquisitions during a financial crisis, we focus our attention on investment measured by capital expenditures. As is standard in difference-in-difference analyses, we include firm and year fixed effects. Furthermore, we cluster standard errors at the firm level to control for autocorrelation (Bertrand, Duflo, and Mullainathan

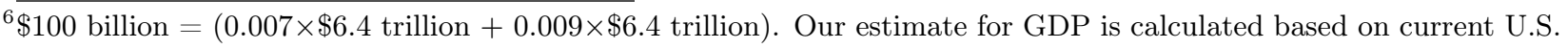
dollar market prices available via The World Bank. 
$(2004))$.

We present the results in Table 4 . We start by examining the United States. We find that firms with a bond rating in 2004 increase their investment somewhat more after the financial crisis. The effect size is 0.3 percentage points in terms of assets and is marginally significant at the 10 percent level. One concern in this set-up is that Rating is correlated with other characteristics such as size or market-to-book ratio and that these variables are causing the effect on investment. In general, it is not a good idea to include time-varying control variables in a difference-in-difference specification, because these variables can be effected by the event and thus are endogenous. Instead, it is a common methodology to fix control variables before the event and interact them with the post event dummy variable. This set-up controls for a differential effect of the event depending on the control variable, such as a bigger effect on larger firms. In Regression 2, we implement this methodology by adding Sales and Market-to-Book measured in 2004 interacted with Post Crisis. After we add these additional controls, the effect of Rating becomes insignificant. This suggests that bond market access does not become more important after the financial crisis for firms in the United States.

Next, we conduct the same analysis for our euro area sample. We present the results in Regressions 3 and 4 of Table 4 . In the euro area, we see a clear increase in the importance of bond market access after the financial crisis. After the crisis, firms with a bond rating increase their capital expenditures by 0.5 percentage points compared to firms without a bond rating. This result is significant at the 5 percent level. After we include the additional Sales and Market-to-Book measured in 2004 interacted with Post Crisis, the effect increases to 0.6 percentage points. This finding is consistent with the strong banking hypothesis: it suggests that firms issue more bonds after the financial crisis when they have less access to bank financing. It is also consistent with the idea that bond market access was less relevant in the euro area before the crisis, because firms had sufficient bank financing and did not need bond market access to fund their investments. 


\subsection{The effect of bond ratings on capital structure}

In addition to investment activity, access to a bond rating may also affect a firm's capital structure. In fact, you would expect a rated firm's leverage to be higher if having a rating allows it to take more credit to invest more. This question is addressed by Faulkender and Petersen (2006), who show that U.S. firms with a bond rating have higher leverage. We replicate their analysis for the United States and extend it to the euro area. We present the results in Table 5. We use the same regression set-up as in Tables 2 and 3. In addition, we also report results lagging Rating by an additional year to better control for endogeneity. We can confirm the result of Faulkender and Petersen (2006) for the United States. U.S. firms with a corporate bond rating have leverage that is 8.4 percentage points or 24 percent higher than that of unrated companies. In contrast, in the euro area we do not find any effect of rating on leverage. In fact the coefficient is actually negative (but only marginally significant). Next, we run our interaction analysis with leverage as the dependent variable. We find that the difference in the effect of bond rating on leverage between the euro area and the United States is both statistically and economically significant. Bond market access increases leverage by 10 percentage points more in the United States than in the euro area. This result is significant at the 1 percent level. Our finding is consistent with the interpretation that a bond rating reduces financial constraints in the United States but not in the euro area. However, it also points to a potential negative effect of stronger bond markets: If stronger bond markets allow firms to take more leverage, they may be more likely to go bankrupt in an economic downturn.

\section{Robustness check}

\subsection{Addressing reverse causality}

One concern is that our results may be affected by reverse causality. It is possible that a firm gets a bond rating in order to invest more and that this behavior is causing the positive association between bond ratings and investment. However it is not clear why such reverse causality would differ between the United States and the euro area, which is necessary for it to drive our effects. 
Nonetheless, we try to address this reversed causality issue by lagging Rating by an additional year, following Harford and Uysal (2014).

We present the results in Table 6. In Panel A, we repeat our analysis for the separate US and euro area samples. Lagging Rating by an additional year does not significantly change our results. The results for the United States remain statistically significant and of similar economic magnitude. The effects in the euro area remain close to zero.

In Panel B, we repeat our analysis on the full sample, where we interact Rating with the euro area dummy variable. For brevity, we do not report the coefficients of the control variables. Similar to Panel A, the extra lag of one year does not change our results. Taken together, these findings suggest that our effect is not driven by reverse causality.

\subsection{Include only firms with at least one acquisition}

One concern with Thomson's SDC platinum is that it only includes acquisitions, but it does not provide a list of firms for which it does not find any acquisitions. In our main specification, we assume that a firm does not undertake an acquisition if no acquisition is listed for it in SDC Platinum. In this robustness check, we conduct a more conservative approach in which we exclude all firms from our sample for which we do not observe at least one acquisition. This ensures that the firm has been successfully matched to Thomson's SDC platinum.

The results are presented in Table 7. Panel A contains a replication of our specification in Table 2, while Panel B contains a replication of our specification in Table 3. In both cases, our results remain of similar statistical and economic magnitude. The difference between the United States and the euro area in terms of Acquisition Value is even slightly larger. This suggests that issues with matching to SDC Platinum are not driving our results. 


\section{Conclusion}

We compare how access to corporate bond markets affects a firm's investment policy and capital structure differently in the United States and the euro area. We measure bond market access by whether a firm has a debt rating. For the United States, we find that firms with a debt rating undertake more acquisitions, spend more on acquisitions, invest more via capital expenditures and have higher leverage. In contrast, we do not find any effects of bond market access on investment in the euro area. These findings suggest that bond market access alleviates financial constraints in the United States, but has no effect in the euro area.

We propose two potential hypotheses to explain why the euro-area corporate bond market seems to be irrelevant for investment. The weak bond market hypothesis suggests that the bond market is too small and insufficiently developed to provide substantial financing to firms. In contrast, the strong banking hypothesis suggests that euro-area firms do not rely much on the bond market, because they can get cheaper financing from euro-area banks. Consistent with the later explanation, we find that the importance of bond market access increases in the euro area when banks are reducing their lending to firms, such as after the 2008-2009 financial crisis.

Our research contributes to a important policy debate on the importance of corporate bond markets for firm investment and whether regulation should help to improve the quality of bond markets in the euro area. Our results suggest that investment in the euro-area would increase by X percent of GDP per year if rated euro-area firms would invest as much as rated U.S. firms. It would increase by an additional X percent of GDP if bond ratings would become as common in the euro area as in the United States. However, our result in favor of the strong banking hypothesis suggest that it is unlikely that such increases in investment would occur even if the euro-area corporate bond markets reaches the size of its U.S. counterpart. Rather, our results seem consistent with euro-area firms choosing not to raise money from corporate bond markets, because they have sufficient access to bank financing (at least before the crisis). Thus, our paper also highlights that prior evidence on the importance of bond market access in the United States cannot be directly applied to more bank-based economies such as the euro area. 


\section{References}

Almeida, Heitor, and Murillo Campello, 2007, Financial constraints, asset tangibility, and corporate investment, Review of Financial Studies 20, 1429-1460.

Almeida, Heitor, Murillo Campello, Bruno Laranjeira, and Scott Weisbenner, 2009, Corporate debt maturity and the real effects of the 2007 credit crisis, NBER Working Paper No. 14990.

Alti, Aydogan, 2003, How sensitive is investment to cash flow when financing is frictionless? Journal of Finance 58, 707-722.

Becker, Bo, and Victoria Ivashina, 2014, Cyclicality of credit supply: Firm level evidence, Journal of Monetary Economics 62, 76-93.

Bertrand, Marianne, Esther Duflo, and Sendhil Mullainathan, 2004, How much should we trust differences-in-differences estimates? Quarterly Journal of Economics 119, 249-275.

Boot, Arnoud WA, and Anjan V. Thakor, 2010, The Accelerating Integration of Banks and Markets and its Implications for Regulation, The Oxford Handbook of Banking, 58-89. n.p.: Oxford and New York: Oxford University Press.

Cecchetti, Stephen G., and Enisse Kharroubi, 2012, Reassessing the impact of finance on growth, BIS Working Papers No. 381.

Chaney, Thomas, David Sraer, and David Thesmar, 2012, The collateral channel: How real estate shocks affect corporate investment, American Economic Review 102, 2381-2409.

Chava, Sudheer, and Amiyatosh Purnanandam, 2011, The effect of banking crisis on bank-dependent borrowers, Journal of Financial Economics 99, 116-135.

De Fiore, Fiorella, and Harald Uhlig, 2005, Bank finance versus bond finance, ECB Working Paper No. 0547.

Diamond, Douglas W, 1984, Financial intermediation and delegated monitoring, Review of Economic Studies 51, 393-414.

Erickson, Timothy, and Toni M. Whited, 2000, Measurement error and the relationship between investment and q, Journal of Political Economy 108, 1027-1057.

Faccio, Mara and Ronald W. Masulis, 2005, The Choice of Payment Method in European Mergers and Acquisitions, Journal of Finance 60, 1345-1388.

Fama, Eugene F., 1985, What's different about banks? Journal of Monetary Economics 15, 29-39.

Faulkender, Michael, and Mitchell A. Petersen, 2006, Does the source of capital affect capital structure? Review of Financial Studies 19, 45-79.

Fazzari, Steven, R. Glenn Hubbard, and Bruce Petersen, 1988, Investment, financing decisions, and tax policy, American Economic Review 78, 200-205. 
Fazzari, Steven M., R. Glenn Hubbard, and Bruce C. Petersen, 2000, Investment-cash flow sensitivities are useful: A comment on Kaplan and Zingales, Quarterly Journal of Economics 115, 695-705.

Gan, Jie, 2007, Collateral, debt capacity, and corporate investment: Evidence from a natural experiment, Journal of Financial Economics 85, 709-734.

Gomes, Joao F, 2001, Financing investment, American Economic Review 91, 1263-1285.

Harford, Jarrad, and Vahap B. Uysal, 2014, Bond market access and investment, Journal of Financial Economics 112, 147-163.

Hoshi, Takeo, Anil Kashyap, and David Scharfstein, 1990, The role of banks in reducing the costs of financial distress in Japan, Journal of Financial Economics 27, 67-88.

Kaplan, Steven N., and Luigi Zingales, 1997, Do investment-cash flow sensitivities provide useful measures of financing constraints?, Quarterly Journal of Economics 112, 169-215.

Kaplan, Steven N., and Luigi Zingales, 2000, Investment-cash flow sensitivities are not valid measures of financing constraints, Quarterly Journal of Economics 115, 707-712.

King, Robert G., and Ross Levine, 1993, Finance, entrepreneurship and growth, Journal of Monetary Economics 32, 513-542.

Law, Siong Hook, and Nirvikar Singh, 2014, Does too much finance harm economic growth? Journal of Banking \& Finance 41, 36-44,

Modigliani, Franco, and Merton H. Miller, 1958, The cost of capital, corporation finance and the theory of investment, American Economic Review 48, 261-297.

Moyen, Nathalie, 2004, Investment cash flow sensitivities: Constrained versus unconstrained firms, Journal of Finance 59, 2061-2092.

Peek, Joe and Eric S. Rosengren, 1990, Collateral Damage: Effects of the Japanese Bank Crisis on Real Activity in the United States, American Economic Review 90, 30-45.

Rajan, Raghuram G., and Luigi Zingales, 1996, Financial dependence and growth, American Economic Review 88, 559-586.

Schnabl, Philipp, 2012, The International Transmission of Bank Liquidity Shocks: Evidence from an Emerging Market, Journal of Finance 67, 897-932.

Sufi, Amir, 2009, The real effects of debt certification: Evidence from the introduction of bank loan ratings, Review of Financial Studies 22, 1659-1691.

Whited, Toni M., 1992, Debt, liquidity constraints, and corporate investment: Evidence from panel data, Journal of Finance 47, 1425-1460. 
Table 1 - Summary Statistics

This table displays summary statistics for firms incorporated in the United States and the euro area over the 20052014 period at a yearly frequency. Rating is a dummy variable equal to one if the firm has either an S\&P or a Moody's issuer rating. Acquisition Dummy is a dummy variable equal to one if the firm undertook at least one acquisition in the year. Acquisition Value/Assets is the sum of the value of all acquisitions that the firm undertook in the year divided by its total book assets. Stock Return is the firm's stock return over the year in percent. Market-to-Book is market value of equity divided by book value of equity. Leverage is debt divided by market value of total assets.

\begin{tabular}{|c|c|c|c|c|c|c|}
\hline \multirow[t]{2}{*}{ Variable } & \multicolumn{3}{|c|}{ United States } & \multicolumn{3}{|c|}{ Euro Area } \\
\hline & Mean & Median & St. Dev. & Mean & Median & St. Dev. \\
\hline Rating & 0.342 & 0 & - & 0.078 & 0 & - \\
\hline Acquisition Dummy & 0.149 & 0 & - & 0.057 & 0 & - \\
\hline Acquisition Value/Assets(in \%) & 2.7 & 0 & 9.6 & 0.6 & 0 & 4.4 \\
\hline Capital Expenditures/Assets(in \%) & 5.4 & 3.3 & 6.3 & 3.5 & 2.4 & 3.9 \\
\hline Assets (USD millions) & 4,271 & 530 & 21,854 & 5,385 & 414 & 21,784 \\
\hline Firm Sales (USD millions) & 2,723 & 468 & 7,052 & 1,662 & 163 & 5,427 \\
\hline Leverage(in \%) & 34.8 & 30.7 & 22.7 & 50.6 & 50.7 & 22.7 \\
\hline Cash/Assets(in \%) & 18.4 & 11.5 & 18.9 & 9.4 & 6.4 & 9.4 \\
\hline EBITDA/Assets(in \%) & 9.7 & 11.5 & 14.7 & 7.4 & 7.5 & 8.0 \\
\hline Stock Return(in \%) & 15.1 & 6.8 & 59.2 & 9.9 & 4.4 & 50.3 \\
\hline Market-to-Book & 1.88 & 1.52 & 1.12 & 1.03 & 0.87 & 0.59 \\
\hline No. of Observations & 22,573 & & & 15,054 & & \\
\hline
\end{tabular}


Table 2 - Investment and acquisitions

This table displays yearly panel regressions studying the effect of debt market access on investment. Regressions 1 and 4 are probit regressions. All other regressions are OLS. In regressions 1 through 3, we use a sample of U.S. firms. In regressions 4 through 6 , we use a sample of firms from the euro area. We use three different dependent variables: Acquisition Dummy is a dummy variable equal to one if the firm undertook at least one acquisition in the year; Acquisition Value is the sum of the value of all acquisitions that the firm undertook in the year divided by its total book assets (in percent); $C A P X$ is defined as capital expenditures divided by total book assets (in percent). All other variables are defined in Appendix B. For probit regressions, we display the marginal effect of the variable Rating at the bottom of the table. All standard errors are clustered at the firm level.

\begin{tabular}{|c|c|c|c|c|c|c|}
\hline & \multicolumn{3}{|c|}{ United States } & \multicolumn{3}{|c|}{ Euro Area } \\
\hline & $\begin{array}{l}\text { Acquisition } \\
\text { Dummy } \\
\text { (1) }\end{array}$ & $\begin{array}{l}\text { Acquisition } \\
\text { Value } \\
\quad(2)\end{array}$ & $\begin{array}{c}\text { CAPX } \\
(3)\end{array}$ & $\begin{array}{l}\text { Acquisition } \\
\text { Dummy } \\
(4)\end{array}$ & $\begin{array}{l}\text { Acquisition } \\
\text { Value } \\
\quad(5)\end{array}$ & $\begin{array}{c}\text { CAPX } \\
(6)\end{array}$ \\
\hline Rating & $\begin{array}{l}0.155^{* * *} \\
(3.84)\end{array}$ & $\begin{array}{l}0.618^{* * *} \\
(3.06)\end{array}$ & $\begin{array}{l}0.784^{* * *} \\
(2.94)\end{array}$ & $\begin{array}{l}0.063 \\
(0.88)\end{array}$ & $\begin{array}{l}-0.077 \\
(-0.62)\end{array}$ & $\begin{array}{c}-0.121 \\
(-0.59)\end{array}$ \\
\hline Sales & $\begin{array}{l}0.072^{* * * *} \\
(6.82)\end{array}$ & $\begin{array}{c}-0.013 \\
(-0.24)\end{array}$ & $\begin{array}{l}-0.324^{* * *} \\
(-4.84)\end{array}$ & $\begin{array}{l}0.114^{* * *} \\
(8.92)\end{array}$ & $\begin{array}{l}0.060^{* * *} \\
(2.97)\end{array}$ & $\begin{array}{l}0.045 \\
(1.24)\end{array}$ \\
\hline Cash & $\begin{array}{l}-0.057 \\
(-0.67)\end{array}$ & $\begin{array}{l}0.066 \\
(0.12)\end{array}$ & $\begin{array}{l}-6.652^{* * *} \\
(-12.91)\end{array}$ & $\begin{array}{l}0.108 \\
(0.49)\end{array}$ & $\begin{array}{l}-0.504 \\
(-1.05)\end{array}$ & $\begin{array}{l}-4.412^{* * *} \\
(-7.54)\end{array}$ \\
\hline Leverage & $\begin{array}{l}-0.937^{* * *} \\
(-10.79)\end{array}$ & $\begin{array}{l}-2.795^{* * *} \\
(-7.99)\end{array}$ & $\begin{array}{l}-0.662 \\
(-1.35)\end{array}$ & $\begin{array}{l}-0.860^{* * *} \\
(-6.88)\end{array}$ & $\begin{array}{l}-1.254^{* * *} \\
(-5.84)\end{array}$ & $\begin{array}{l}-1.110^{* * *} \\
(-3.24)\end{array}$ \\
\hline Stock Return & $\begin{array}{l}0.099^{* * *} \\
(4.98)\end{array}$ & $\begin{array}{l}0.468^{* * *} \\
(3.68)\end{array}$ & $\begin{array}{l}0.479^{* * *} \\
(5.58)\end{array}$ & $\begin{array}{l}0.168^{* * *} \\
(4.37)\end{array}$ & $\begin{array}{l}0.081 \\
(0.91)\end{array}$ & $\begin{array}{l}0.546^{* * *} \\
(5.54)\end{array}$ \\
\hline Market-to-Book & $\begin{array}{l}-0.077^{* * *} \\
(-5.30)\end{array}$ & $\begin{array}{l}-0.030 \\
(-0.35)\end{array}$ & $\begin{array}{l}0.571^{* * *} \\
(7.15)\end{array}$ & $\begin{array}{l}-0.103^{* *} \\
(-2.30)\end{array}$ & $\begin{array}{l}0.058 \\
(0.53)\end{array}$ & $\begin{array}{l}0.011 \\
(0.08)\end{array}$ \\
\hline Earnings & $\begin{array}{l}0.315^{* * *} \\
(2.99)\end{array}$ & $\begin{array}{l}2.305^{* * *} \\
(4.46)\end{array}$ & $\begin{array}{l}7.702^{* * *} \\
(14.27)\end{array}$ & $\begin{array}{l}-0.126 \\
(-0.40)\end{array}$ & $\begin{array}{l}-0.529 \\
(-0.82)\end{array}$ & $\begin{array}{l}8.516^{* * * *} \\
(8.18)\end{array}$ \\
\hline M\&A Liquidity & $\begin{array}{l}2.433^{* * *} \\
(8.16)\end{array}$ & $\begin{array}{l}27.065^{* * *} \\
(10.77)\end{array}$ & & $\begin{array}{l}5.969^{* * *} \\
(10.80)\end{array}$ & $\begin{array}{l}34.107^{* * *} \\
(7.73)\end{array}$ & \\
\hline Herfindahl Index & $\begin{array}{l}-0.557^{* * *} \\
(-5.26)\end{array}$ & $\begin{array}{l}-1.517^{* * *} \\
(-4.98)\end{array}$ & & $\begin{array}{l}-0.584^{* * *} \\
(-3.61)\end{array}$ & $\begin{array}{l}-0.262^{*} \\
(-1.84)\end{array}$ & \\
\hline Marginal Effect(in \%): Rating & 3.49 & - & - & 0.69 & - & - \\
\hline Year Fixed Effects & Yes & Yes & Yes & Yes & Yes & Yes \\
\hline No. of Observations & 22,573 & 22,573 & 22,573 & 15,054 & 15,054 & 15,054 \\
\hline
\end{tabular}

$t$ statistics in parentheses

${ }^{*} p<0.1,{ }^{* *} p<0.05,{ }^{* * *} p<0.01$ 
Table 3 - Interaction analysis

This table displays yearly panel regressions studying the relative effect of debt market access on investment for firms in the euro area compared to firms in the United States. The sample consists of both U.S. and euro area firms. Regressions 1 is a probit regression. All other regressions are OLS. We use three different dependent variables: Acquisition Dummy is a dummy variable equal to one if the firm undertook at least one acquisition in the year; Acquisition Value is the sum of the value of all acquisitions that the firm undertook in the year divided by its total book assets (in percent); CAPX is defined as capital expenditures divided by total book assets (in percent). All other variables are defined in Appendix B. For probit regressions, we display the marginal effect of the variable interaction Euro Area $x$ Rating at the bottom of the table. All standard errors are clustered at the firm level.

\begin{tabular}{|c|c|c|c|}
\hline & $\begin{array}{l}\text { Acquisition } \\
\text { Dummy } \\
\text { (1) }\end{array}$ & $\begin{array}{l}\text { Acquisition } \\
\text { Value } \\
(2)\end{array}$ & $\begin{array}{c}\text { CAPX } \\
(3)\end{array}$ \\
\hline Euro Area x Rating & $\begin{array}{l}-0.103 \\
(-1.26)\end{array}$ & $\begin{array}{l}-0.715^{* * *} \\
(-3.03)\end{array}$ & $\begin{array}{l}-0.928^{* * *} \\
(-2.75)\end{array}$ \\
\hline Euro Area & $\begin{array}{l}-0.574^{* * *} \\
(-3.99)\end{array}$ & $\begin{array}{l}-1.932^{* * *} \\
(-3.86)\end{array}$ & $\begin{array}{l}-3.165 * * * \\
(-5.23)\end{array}$ \\
\hline Rating & $\begin{array}{l}0.155^{* * *} \\
(3.86)\end{array}$ & $\begin{array}{l}0.619^{* * *} \\
(3.07)\end{array}$ & $\begin{array}{l}0.779^{* * *} \\
(2.92)\end{array}$ \\
\hline Sales & $\begin{array}{l}0.074^{* * *} \\
(6.95)\end{array}$ & $\begin{array}{c}-0.008 \\
(-0.16)\end{array}$ & $\begin{array}{l}-0.315^{* * *} \\
(-4.72)\end{array}$ \\
\hline Euro Area x Sales & $\begin{array}{l}0.040^{* *} \\
(2.39)\end{array}$ & $\begin{array}{l}0.069 \\
(1.21)\end{array}$ & $\begin{array}{l}0.359^{* * *} \\
(4.73)\end{array}$ \\
\hline Cash & $\begin{array}{l}-0.055 \\
(-0.64)\end{array}$ & $\begin{array}{l}0.086 \\
(0.16)\end{array}$ & $\begin{array}{l}-6.605^{* * *} \\
(-12.90)\end{array}$ \\
\hline Euro Area x Cash & $\begin{array}{l}0.151 \\
(0.65)\end{array}$ & $\begin{array}{l}-0.619 \\
(-0.88)\end{array}$ & $\begin{array}{l}2.129^{* * *} \\
(2.76)\end{array}$ \\
\hline Leverage & $\begin{array}{l}-0.945^{* * *} \\
(-10.91)\end{array}$ & $\begin{array}{l}-2.821 * * * \\
(-8.10)\end{array}$ & $\begin{array}{c}-0.664 \\
(-1.36)\end{array}$ \\
\hline Euro Area x Leverage & $\begin{array}{l}0.099 \\
(0.67)\end{array}$ & $\begin{array}{l}1.570^{* * *} \\
(3.85)\end{array}$ & $\begin{array}{l}-0.446 \\
(-0.75)\end{array}$ \\
\hline Stock Return & $\begin{array}{l}0.113^{* * *} \\
(5.77)\end{array}$ & $\begin{array}{l}0.508^{* * *} \\
(4.20)\end{array}$ & $\begin{array}{l}0.511^{* * *} \\
(6.18)\end{array}$ \\
\hline Euro Area x Stock Return & $\begin{array}{l}0.017 \\
(0.41)\end{array}$ & $\begin{array}{l}-0.477^{* * *} \\
(-3.42)\end{array}$ & $\begin{array}{l}0.008 \\
(0.07)\end{array}$ \\
\hline Market-to-Book & $\begin{array}{l}-0.079 * * * \\
(-5.42)\end{array}$ & $\begin{array}{l}-0.036 \\
(-0.42)\end{array}$ & $\begin{array}{l}0.559^{* * *} \\
(7.06)\end{array}$ \\
\hline Euro Area x Market-to-Book & $\begin{array}{l}-0.017 \\
(-0.37)\end{array}$ & $\begin{array}{l}0.106 \\
(0.75)\end{array}$ & $\begin{array}{l}-0.509^{* * *} \\
(-3.38)\end{array}$ \\
\hline Earnings & $\begin{array}{l}0.313^{* * *} \\
(2.99)\end{array}$ & $\begin{array}{l}2.309^{* * *} \\
(4.48)\end{array}$ & $\begin{array}{l}7.720^{* * *} \\
(14.34)\end{array}$ \\
\hline Euro Area x Earnings & $\begin{array}{l}-0.370 \\
(-1.12)\end{array}$ & $\begin{array}{l}-2.704^{* * *} \\
(-3.30)\end{array}$ & $\begin{array}{l}0.946 \\
(0.81)\end{array}$ \\
\hline M\&A Liquidity & $\begin{array}{l}2.430^{* * *} \\
(8.19)\end{array}$ & $\begin{array}{l}27.021^{\text {*** }} \\
(10.82)\end{array}$ & \\
\hline Euro Area x M\&A Liquidity & $\begin{array}{l}3.598^{* * *} \\
(5.80)\end{array}$ & $\begin{array}{l}7.201 \\
(1.43)\end{array}$ & \\
\hline Herfindahl Index & $\begin{array}{l}-0.550^{* * *} \\
(-5.23)\end{array}$ & $\begin{array}{l}-1.503^{* * *} \\
(-4.93)\end{array}$ & \\
\hline Euro Area x Herfindahl & $\begin{array}{c}-0.045 \\
(-0.23)\end{array}$ & $\begin{array}{l}1.231^{* * *} \\
(3.67)\end{array}$ & \\
\hline Marg. Effect(in \%): Euro Area x Rating & -1.70 & - & - \\
\hline Year Fixed Effects & Yes & Yes & Yes \\
\hline No. of Observations & 37,627 & 37,627 & 37,627 \\
\hline
\end{tabular}


Table 4 - Difference-in-difference after the 2009 financial crisis

This table displays results of a difference-in-differences analysis studying how the effect of debt market access on investment changed after the financial crisis of 2008. In regressions 1 and 2, we use a sample of U.S. firms. In regressions 3 and 4, we use a sample of euro-area firms. Our dependent variable is $C A P X$, defined as capital expenditures divided by total book assets. The explanatory variable of interest is the interaction between Rating and Post Crisis. Post Crisis is a dummy variable equal to one from 2009 to 2014 and equal to zero from 2005 to 2007. We exclude 2008 from the sample. Rating, Sales, and Market-to-Book are taken as of 2004. All standard errors are clustered at the firm level.

\begin{tabular}{|c|c|c|c|c|}
\hline & \multicolumn{2}{|c|}{ United States } & \multicolumn{2}{|c|}{ Euro Area } \\
\hline & $\begin{array}{l}\text { CAPX } \\
(1)\end{array}$ & $\begin{array}{l}\text { CAPX } \\
(2)\end{array}$ & $\begin{array}{l}\text { CAPX } \\
(3)\end{array}$ & $\begin{array}{c}\text { CAPX } \\
(4)\end{array}$ \\
\hline Rating $_{04} \times$ Post Crisis & $\begin{array}{l}0.300^{*} \\
(1.70)\end{array}$ & $\begin{array}{l}0.073 \\
(0.29)\end{array}$ & $\begin{array}{l}0.530^{* *} \\
(2.28)\end{array}$ & $\begin{array}{l}0.570^{*} \\
(1.84)\end{array}$ \\
\hline Sales $_{04} \times$ Post Crisis & & $\begin{array}{l}0.035 \\
(0.52)\end{array}$ & & $\begin{array}{l}-0.013 \\
(-0.23)\end{array}$ \\
\hline Market-to-Book $_{04} \times$ Post Crisis & & $\begin{array}{l}-0.335^{* * *} \\
(-4.12)\end{array}$ & & $\begin{array}{l}-0.092 \\
(-0.74)\end{array}$ \\
\hline Firm Fixed Effect & Yes & Yes & Yes & Yes \\
\hline Year Fixed Effects & Yes & Yes & Yes & Yes \\
\hline No. of Observations & 16,084 & 16,084 & 10,797 & 10,797 \\
\hline
\end{tabular}


Table 5 - Capital Structure

This table displays yearly panel regressions studying the effect of debt market access on a firm's capital structure. In Panel A, we use the same regression set-up as in Table 2. In Panel B, we use the the same regression set-up as in Table 3. In Panel B, we include the following control variables whose coefficients are not reported for brevity: Sales, Cash, Leverage, Stock Return, Market-to-Book, Earnings and these variables interacted with Euro Area. In regressions 2 and 4, we lag Rating by an extra year (Rating t-2 ). Leverage is defined as book assets minus book equity, divided by market value of equity. All other variables are defined in Appendix B. All standard errors are clustered at the firm level.

\begin{tabular}{|c|c|c|c|c|}
\hline & \multicolumn{2}{|c|}{ United States } & \multicolumn{2}{|c|}{ Euro Area } \\
\hline & $\begin{array}{l}\text { Leverage } \\
\text { (1) }\end{array}$ & $\begin{array}{l}\text { Leverage } \\
(2)\end{array}$ & $\begin{array}{l}\text { Leverage } \\
\text { (3) }\end{array}$ & $\begin{array}{l}\text { Leverage } \\
\text { (4) }\end{array}$ \\
\hline Rating & $\begin{array}{l}0.084^{* * *} \\
(11.46)\end{array}$ & & $\begin{array}{l}-0.020^{*} \\
(-1.69)\end{array}$ & \\
\hline Rating $_{\mathrm{t}-2}$ & & $\begin{array}{l}0.083^{* * *} \\
(10.77)\end{array}$ & & $\begin{array}{c}-0.017 \\
(-1.29)\end{array}$ \\
\hline Sales & $\begin{array}{l}0.002 \\
(1.02)\end{array}$ & $\begin{array}{l}0.003 \\
(1.19)\end{array}$ & $\begin{array}{l}0.012^{* * *} \\
(5.80)\end{array}$ & $\begin{array}{l}0.012^{* * *} \\
(5.21)\end{array}$ \\
\hline Cash & $\begin{array}{l}-0.386^{* * *} \\
(-28.36)\end{array}$ & $\begin{array}{l}-0.393^{* * *} \\
(-26.34)\end{array}$ & $\begin{array}{l}-0.570 * * * \\
(-17.54)\end{array}$ & $\begin{array}{l}-0.571^{* * *} \\
(-15.75)\end{array}$ \\
\hline Stock Return & $\begin{array}{c}-0.004 \\
(-1.49)\end{array}$ & $\begin{array}{c}-0.005^{*} \\
(-1.74)\end{array}$ & $\begin{array}{l}-0.034^{* * *} \\
(-6.99)\end{array}$ & $\begin{array}{l}-0.039 * * * \\
(-7.32)\end{array}$ \\
\hline Market-to-Book & $\begin{array}{l}-0.060 * * * \\
(-25.40)\end{array}$ & $\begin{array}{l}-0.063 * * * \\
(-23.27)\end{array}$ & $\begin{array}{l}-0.137^{* * *} \\
(-13.13)\end{array}$ & $\begin{array}{l}-0.142 * * * \\
(-11.72)\end{array}$ \\
\hline Earnings & $\begin{array}{l}-0.356^{* * *} \\
(-22.25)\end{array}$ & $\begin{array}{l}-0.349^{* * *} \\
(-20.10)\end{array}$ & $\begin{array}{l}-0.727^{* * *} \\
(-16.32)\end{array}$ & $\begin{array}{l}-0.765^{* * *} \\
(-15.51)\end{array}$ \\
\hline Year Fixed Effects & Yes & Yes & Yes & Yes \\
\hline No. of Observations & 21,924 & 18,558 & 14,808 & 12,677 \\
\hline \multicolumn{3}{|l|}{ Panel B: Interaction Analysis } & & \\
\hline & $\begin{array}{l}\text { Leverage } \\
\text { (1) }\end{array}$ & $\begin{array}{l}\text { Leverage } \\
(2)\end{array}$ & & \\
\hline Euro Area $x$ Rating & $\begin{array}{l}-0.103^{* * *} \\
(-7.36)\end{array}$ & & & \\
\hline Euro Area x Rating $\mathrm{t}_{\mathrm{t}-2}$ & & $\begin{array}{l}-0.099 * * * \\
(-6.62)\end{array}$ & & \\
\hline Rating & $\begin{array}{l}0.084^{* * *} \\
(11.47)\end{array}$ & & & \\
\hline Rating $_{\mathrm{t}-2}$ & & $\begin{array}{l}0.083^{* * *} \\
(10.77)\end{array}$ & & \\
\hline Euro Area & $\begin{array}{l}0.167^{* * * *} \\
(8.17)\end{array}$ & $\begin{array}{l}0.180^{* * * *} \\
(8.21)\end{array}$ & & \\
\hline Control Effects & Yes & Yes & & \\
\hline Euro Area x Control Effects & Yes & Yes & & \\
\hline Year Fixed Effects & Yes & Yes & & \\
\hline No. of Observations & 36,732 & 31,235 & & \\
\hline
\end{tabular}


Table 6 - Robustness check: Lagged firm bond ratings

This table displays results of a robustness check in which we lag Rating by an extra year (Rating $\mathrm{t}-2$ ). In Panel A, we use the same regression set-up as in Table 2. In Panel B, we use the the same regression set-up as in Table 3 . In Panel B, we include the following control variables whose coefficients are not reported for brevity: Sales, Cash, Leverage, Stock Return, Market-to-Book, Earnings and these variables interacted with Euro Area. In Regressions 1 and 2 of Panel B, we also include MEGA Liquidity, Herfindahl Index and these variables interacted with Euro Area. All other variables are defined in Appendix B. Regressions 1 and 4 are probit regressions. All other regressions are OLS. We use three different dependent variables: Acquisition Dummy is a dummy variable equal to one if the firm undertook at least one acquisition in the year; Acquisition Value is the sum of the value of all acquisitions that the firm undertook in the year divided by its total book assets (in percent); CAPX is defined as capital expenditures divided by total book assets (in percent). All standard errors are clustered at the firm level.

Panel A: Robustness Check for Table 2

\begin{tabular}{|c|c|c|c|c|c|c|}
\hline & \multicolumn{3}{|c|}{ United States } & \multicolumn{3}{|c|}{ Euro Area } \\
\hline & $\begin{array}{l}\text { Acquisition } \\
\text { Dummy } \\
\text { (1) }\end{array}$ & $\begin{array}{l}\text { Acquisition } \\
\text { Value } \\
\quad(2)\end{array}$ & $\begin{array}{l}\text { CAPX } \\
(3)\end{array}$ & $\begin{array}{l}\text { Acquisition } \\
\text { Dummy } \\
(4)\end{array}$ & $\begin{array}{l}\text { Acquisition } \\
\text { Value } \\
\quad(5)\end{array}$ & $\begin{array}{c}\text { CAPX } \\
(6)\end{array}$ \\
\hline Rating $_{\mathrm{t}-2}$ & $\begin{array}{l}0.127^{* * *} \\
(2.93)\end{array}$ & $\begin{array}{l}0.476^{* *} \\
(2.21)\end{array}$ & $\begin{array}{l}0.562^{* *} \\
(2.08)\end{array}$ & $\begin{array}{l}0.057 \\
(0.73)\end{array}$ & $\begin{array}{l}-0.030 \\
(-0.24)\end{array}$ & $\begin{array}{c}-0.134 \\
(-0.64)\end{array}$ \\
\hline Sales & $\begin{array}{l}0.078^{* * *} \\
(6.77)\end{array}$ & $\begin{array}{l}-0.005 \\
(-0.08)\end{array}$ & $\begin{array}{l}-0.264^{* * *} \\
(-3.91)\end{array}$ & $\begin{array}{l}0.115^{* * *} \\
(8.54)\end{array}$ & $\begin{array}{l}0.048^{* *} \\
(2.35)\end{array}$ & $\begin{array}{l}0.056 \\
(1.54)\end{array}$ \\
\hline Cash & $\begin{array}{c}-0.009 \\
(-0.10)\end{array}$ & $\begin{array}{l}0.374 \\
(0.64)\end{array}$ & $\begin{array}{l}-6.655^{* * *} \\
(-12.14)\end{array}$ & $\begin{array}{l}0.257 \\
(1.05)\end{array}$ & $\begin{array}{l}0.020 \\
(0.04)\end{array}$ & $\begin{array}{l}-4.095^{* * *} \\
(-6.70)\end{array}$ \\
\hline Leverage & $\begin{array}{l}-0.904^{* * *} \\
(-9.66)\end{array}$ & $\begin{array}{l}-2.608^{* * *} \\
(-6.96)\end{array}$ & $\begin{array}{l}-0.403 \\
(-0.78)\end{array}$ & $\begin{array}{l}-0.767^{* * *} \\
(-5.72)\end{array}$ & $\begin{array}{l}-1.027^{* * *} \\
(-4.93)\end{array}$ & $\begin{array}{l}-1.143^{* * *} \\
(-3.33)\end{array}$ \\
\hline Stock Return & $\begin{array}{l}0.115^{* * *} \\
(5.12)\end{array}$ & $\begin{array}{l}0.564^{* * *} \\
(3.97)\end{array}$ & $\begin{array}{l}0.536^{* * *} \\
(5.72)\end{array}$ & $\begin{array}{l}0.164 * * * \\
(3.78)\end{array}$ & $\begin{array}{l}0.110 \\
(1.17)\end{array}$ & $\begin{array}{l}0.597^{* * *} \\
(5.56)\end{array}$ \\
\hline Market-to-Book & $\begin{array}{l}-0.087^{* * *} \\
(-5.33)\end{array}$ & $\begin{array}{l}-0.080 \\
(-0.85)\end{array}$ & $\begin{array}{l}0.524^{* * *} \\
(6.04)\end{array}$ & $\begin{array}{l}-0.112^{* *} \\
(-2.26)\end{array}$ & $\begin{array}{l}0.074 \\
(0.69)\end{array}$ & $\begin{array}{l}-0.113 \\
(-0.95)\end{array}$ \\
\hline Earnings & $\begin{array}{l}0.324^{* * *} \\
(2.75)\end{array}$ & $\begin{array}{l}2.448^{* * *} \\
(4.48)\end{array}$ & $\begin{array}{l}7.889 * * * \\
(13.86)\end{array}$ & $\begin{array}{l}0.034 \\
(0.10)\end{array}$ & $\begin{array}{c}-0.488 \\
(-0.76)\end{array}$ & $\begin{array}{l}9.140^{* * *} \\
(8.49)\end{array}$ \\
\hline M\&A Liquidity & $\begin{array}{l}3.025^{* * *} \\
(5.88)\end{array}$ & $\begin{array}{l}29.388^{* * *} \\
(9.79)\end{array}$ & & $\begin{array}{l}6.273^{* * *} \\
(9.26)\end{array}$ & $\begin{array}{l}34.752^{* * *} \\
(6.84)\end{array}$ & \\
\hline Herfindahl Index & $\begin{array}{l}-0.579^{* * *} \\
(-5.10)\end{array}$ & $\begin{array}{l}-1.615^{* * *} \\
(-5.29)\end{array}$ & & $\begin{array}{l}-0.526^{* * *} \\
(-3.06)\end{array}$ & $\begin{array}{l}-0.213 \\
(-1.47)\end{array}$ & \\
\hline Marginal Effect(in \%): Rating ${ }_{t-2}$ & 2.83 & - & - & 0.60 & - & - \\
\hline Year Fixed Effects & Yes & Yes & Yes & Yes & Yes & Yes \\
\hline No. of Observations & 19,101 & 19,101 & 19,101 & 12,894 & 12,894 & 12,894 \\
\hline
\end{tabular}

\begin{tabular}{|c|c|c|c|}
\hline & $\begin{array}{l}\text { Acquisition } \\
\text { Dummy } \\
\text { (1) }\end{array}$ & $\begin{array}{l}\text { Acquisition } \\
\text { Value } \\
\quad(2)\end{array}$ & $\begin{array}{c}\text { CAPX } \\
(3)\end{array}$ \\
\hline Euro Area $\mathrm{x}$ Rating t-2 & $\begin{array}{l}-0.077 \\
(-0.87)\end{array}$ & $\begin{array}{l}-0.518^{* *} \\
(-2.06)\end{array}$ & $\begin{array}{l}-0.708^{* *} \\
(-2.08)\end{array}$ \\
\hline Euro Area & $\begin{array}{l}-0.615^{* * *} \\
(-3.97)\end{array}$ & $\begin{array}{l}-1.969^{* * *} \\
(-3.74)\end{array}$ & $\begin{array}{l}-2.861^{* * *} \\
(-4.70)\end{array}$ \\
\hline Rating $_{\mathrm{t}-2}$ & $\begin{array}{l}0.126^{* * *} \\
(2.93)\end{array}$ & $\begin{array}{l}0.475^{* *} \\
(2.21)\end{array}$ & $\begin{array}{l}0.558^{* *} \\
(2.06)\end{array}$ \\
\hline Marg. Effect(in \%): E.A. x Rating t-2 & -1.28 & - & - \\
\hline Control Effects & Yes & Yes & Yes \\
\hline Year Fixed Effects & Yes & Yes & Yes \\
\hline No. of Observations & 31,995 & 31,995 & 31,995 \\
\hline
\end{tabular}

$t$ statistics in parentheses

${ }^{*} p<0.1,{ }^{* *} p<0.05,{ }^{* * *} p<0.01$ 
Table 7 - Robustness check: Only firms with at least one acquisition

This table displays results of a robustness check in which we exclude all firms from our sample for which we do not observe at least one acquisition. In Panel A, we use the same regression set-up as in Table 2. In Panel B, we use the the same regression set-up as in Table 3. In Panel B, we include the following control variables whose coefficients are not reported for brevity: Sales, Cash, Leverage, Stock Return, Market-to-Book, Earnings, MEA Liquidity, Herfindahl Index and these variables interacted with Euro Area. All other variables are defined in Appendix B. Regressions 1 and 3 are probit regressions. All other regressions are OLS. We use two different dependent variables: Acquisition Dummy is a dummy variable equal to one if the firm undertook at least one acquisition in the year; Acquisition Value is the sum of the value of all acquisitions that the firm undertook in the year divided by its total book assets (in percent). All standard errors are clustered at the firm level.

\begin{tabular}{|c|c|c|c|c|}
\hline & \multicolumn{2}{|c|}{ United States } & \multicolumn{2}{|c|}{ Euro Area } \\
\hline & $\begin{array}{l}\text { Acquisition } \\
\text { Dummy } \\
\quad(1)\end{array}$ & $\begin{array}{l}\text { Acquisition } \\
\text { Value } \\
\quad(2)\end{array}$ & $\begin{array}{l}\text { Acquisition } \\
\text { Dummy } \\
\quad(3)\end{array}$ & $\begin{array}{l}\text { Acquisition } \\
\text { Value } \\
(4)\end{array}$ \\
\hline Rating & $\begin{array}{l}0.127^{* * *} \\
(3.25)\end{array}$ & $\begin{array}{l}0.862^{* * *} \\
(3.07)\end{array}$ & $\begin{array}{l}0.088 \\
(1.22)\end{array}$ & $\begin{array}{l}0.033 \\
(0.19)\end{array}$ \\
\hline Sales & $\begin{array}{l}0.027^{* *} \\
(2.51)\end{array}$ & $\begin{array}{l}-0.434^{* * *} \\
(-5.35)\end{array}$ & $\begin{array}{l}0.007 \\
(0.48)\end{array}$ & $\begin{array}{l}-0.162^{* * *} \\
(-3.63)\end{array}$ \\
\hline Cash & $\begin{array}{l}0.136 \\
(1.51)\end{array}$ & $\begin{array}{l}1.475^{*} \\
(1.70)\end{array}$ & $\begin{array}{l}0.629^{* *} \\
(2.40)\end{array}$ & $\begin{array}{l}0.522 \\
(0.39)\end{array}$ \\
\hline Leverage & $\begin{array}{l}-0.636^{* * *} \\
(-6.91)\end{array}$ & $\begin{array}{l}-2.185^{* * *} \\
(-3.56)\end{array}$ & $\begin{array}{l}-0.847^{* * *} \\
(-5.58)\end{array}$ & $\begin{array}{l}-2.378^{* * *} \\
(-4.17)\end{array}$ \\
\hline Stock Return & $\begin{array}{l}0.119^{* * *} \\
(4.89)\end{array}$ & $\begin{array}{l}0.848^{* * *} \\
(3.71)\end{array}$ & $\begin{array}{l}0.257^{* * *} \\
(5.08)\end{array}$ & $\begin{array}{l}0.296 \\
(1.28)\end{array}$ \\
\hline Market-to-Book & $\begin{array}{l}-0.040^{* *} \\
(-2.48)\end{array}$ & $\begin{array}{l}0.321^{* *} \\
(2.00)\end{array}$ & $\begin{array}{l}-0.135^{*} \\
(-1.92)\end{array}$ & $\begin{array}{l}0.273 \\
(0.75)\end{array}$ \\
\hline Earnings & $\begin{array}{l}0.383^{* * *} \\
(3.02)\end{array}$ & $\begin{array}{l}3.648^{* * *} \\
(3.59)\end{array}$ & $\begin{array}{l}0.331 \\
(0.82)\end{array}$ & $\begin{array}{c}-0.750 \\
(-0.41)\end{array}$ \\
\hline M\&A Liquidity & $\begin{array}{l}3.052^{* * * *} \\
(11.44)\end{array}$ & $\begin{array}{l}36.826^{* * *} \\
(12.77)\end{array}$ & $\begin{array}{l}7.929^{* * *} \\
(7.85)\end{array}$ & $\begin{array}{l}56.643^{* * *} \\
(9.08)\end{array}$ \\
\hline Herfindahl Index & $\begin{array}{l}-0.453^{* * *} \\
(-4.82)\end{array}$ & $\begin{array}{l}-2.379^{* * *} \\
(-6.13)\end{array}$ & $\begin{array}{l}-0.466^{* * *} \\
(-3.45)\end{array}$ & $\begin{array}{l}-0.903^{* * *} \\
(-3.37)\end{array}$ \\
\hline Marginal Effect(in \%): Rating & 3.83 & - & 1.78 & - \\
\hline Year Fixed Effects & Yes & Yes & Yes & Yes \\
\hline No. of Observations & 13,867 & 13,867 & 6,594 & 6,594 \\
\hline
\end{tabular}

Panel B: Robustness Check for Table 3

\begin{tabular}{lll}
\hline & $\begin{array}{l}\text { Acquisition } \\
\text { Dummy } \\
(1)\end{array}$ & $\begin{array}{l}\text { Acquisition } \\
\text { Value } \\
(2)\end{array}$ \\
\hline Euro Area x Rating & -0.056 & $-0.882^{* * *}$ \\
& $(-0.69)$ & $(-2.68)$ \\
Euro Area & -0.006 & $-2.423^{* *}$ \\
& $(-0.03)$ & $(-2.51)$ \\
Rating & $0.128^{* * *}$ & $0.865^{* * *}$ \\
& $(3.30)$ & $(3.08)$ \\
\hline Marg. Effect(in \%): Euro Area x Rating & -1.46 & - \\
Control Effects & Yes & Yes \\
Year Fixed Effects & Yes & Yes \\
No. of Observations & 20,461 & 20,461 \\
\hline
\end{tabular}

$t$ statistics in parentheses

* $p<0.1, * * p<0.05$, *** $p<0.01$ 


\section{Appendix A - Summary statistics by country}

This table presents summary statistics of our main variables, broken down by country. Rating and CAPX present the average of both variables over all firm-year observations of firms in that country. Number of Acquisitions displays the total number of country-associated firm- years where Acquisition Dummy is equal to 1. Observations displays the total number of firm-years of firms in that country.

Summary Statistics by Country

\begin{tabular}{lrrrr}
\hline Country & Rating & $\begin{array}{c}\text { CAPX } \\
\text { (in \%) }\end{array}$ & $\begin{array}{r}\text { Number of } \\
\text { Acquisitions }\end{array}$ & Observations \\
\hline Greece & 0.019 & 3.2 & 46 & 1,579 \\
Belgium & 0.033 & 4.4 & 29 & 646 \\
Finland & 0.053 & 3.7 & 85 & 960 \\
Austria & 0.058 & 5.3 & 22 & 449 \\
Spain & 0.068 & 3.3 & 82 & 734 \\
Italy & 0.070 & 2.8 & 118 & 1,466 \\
Portugal & 0.080 & 3.1 & 36 & 373 \\
Germany & 0.083 & 3.8 & 150 & 3,841 \\
France & 0.097 & 3.3 & 214 & 3,831 \\
Netherlands & 0.116 & 3.7 & 62 & 813 \\
Ireland & 0.184 & 2.5 & 15 & 244 \\
Luxembourg & 0.314 & 4.6 & 4 & 118 \\
\hline Totals & & & & \\
Euro Area & 0.078 & 3.5 & 863 & 15,054 \\
United States & 0.342 & 5.4 & 3,374 & 22,573 \\
Overall & 0.237 & 4.7 & 4,237 & 37,627 \\
\hline
\end{tabular}




\section{Appendix B - Variable definitions}

This table shows variable definitions of all variables used in the regressions in alphabetical order. All variables are on the firm-year level. Firm subscripts are omitted for brevity. All continuous variable are winsorized at the 1 and 99 percent levels.

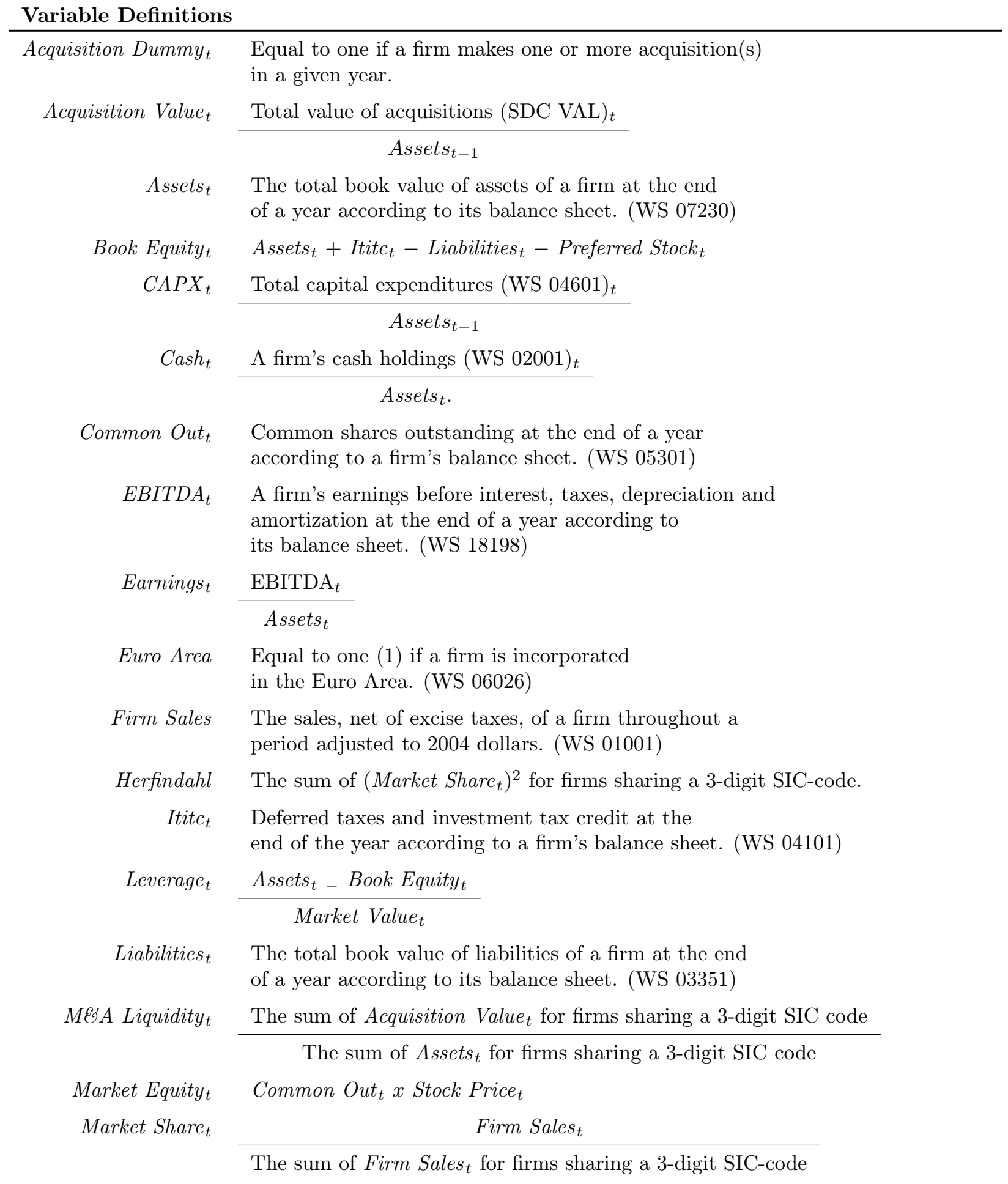

Data Source in parentheses:

$W S=$ Worldscope Item, $S D C=S D C$ Platinum MES Item, $M C E=$ Moody's CreditEdge 
Variable Definitions, cont.

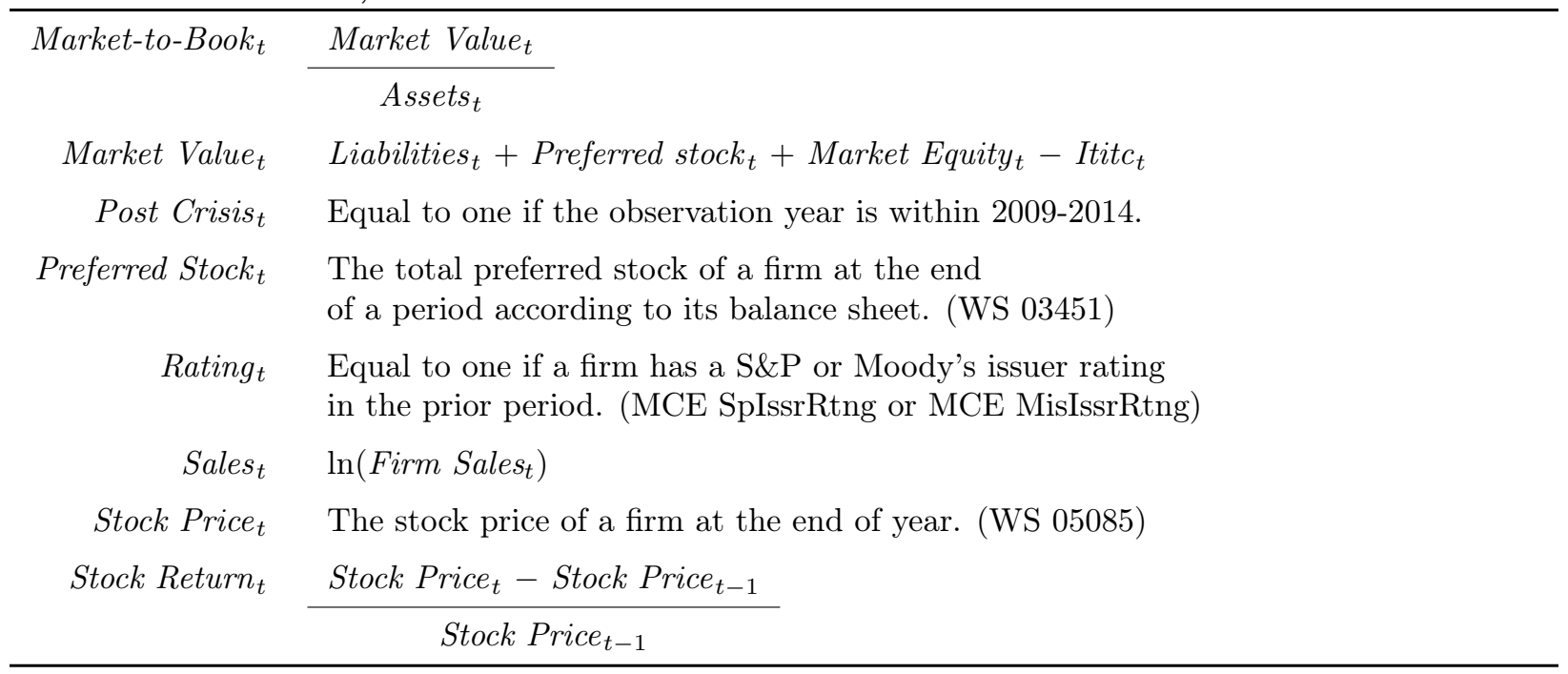

Data Source in parentheses:

$W S=$ Worldscope Item, $S D C=S D C$ Platinum MESA Item, MCE = Moody's CreditEdge 